\title{
Ideas and Change in Foreign Policy Instruments: Soft Power and the Case of the Turkish International Cooperation and Development Agency
}

\author{
PINAR IPEK
}

Bilkent University

\begin{abstract}
Constructivism in the International Relations literature mainly focuses on the constitutive interaction between international norms and state actions. Few studies explore when ideas at the domestic level matter in foreign policy change. I propose a constructivist account for policy change that emphasizes not only ideas but also material interests as exogenous factors constituted within domestic structures. My empirical analysis in the case of the Turkish International Cooperation and Development Agency reveals important evidence demonstrating the influence of (i) shared normative values, mostly constituted by the foreign policy elite's intersubjective understanding of Turkey's historical roots and cultural ties in the region and (ii) material interests, favored through the "trading state" and framed by the convergence of principled and causal beliefs on policy change. Ideas matter in foreign policymaking when a set of contingent conditions is satisfied: (i) A small group of recognized foreign policy elite has shared normative beliefs and (ii) an enabling political environment exists, particularly a majority government facilitating foreign policy appointments to key positions so that a window of opportunity is provided for policy entrepreneurship.
\end{abstract}

There is growing literature on the role of ideas in International Relations but the conditions under which ideas influence foreign policy change are understudied. Constructivism treats ideas as structural factors and considers the dynamic relationship between ideas and material forces (Adler 2002). However, constructivist scholars mainly focus on international norms and rules and the constitutive interaction between norms and state actions. Few studies explore when ideas at the domestic level matter in foreign policy change, and thus, this study attempts to fill this empirical gap. I consider the role of ideas as an explanatory variable and argue that a specific set of conditions at the domestic level are required for ideational influence to constitute normative values and material interests in foreign policy.

The pioneering studies focusing on how ideas influence foreign policy underline how the significance of the domestic context specifies the process for policy change. For example, Risse-Kappen's (1994) seminal study explaining the end of the Cold War stresses the importance of a state's domestic structures in determining the conditions under which particular ideas of the "epistemic communities" in international organizations or transnational networks lead foreign policy change. Other scholars highlight the institutional conditions under which ideas persist and thus determine policy (Hall 1989; Sikkink 1991; Goldstein and 
Keohane 1993; Woods 1995; Finnemore 1996; Checkel 1997). Recent studies elaborate on causal mechanisms linking ideas to foreign policy (Ozkececi-Taner 2005; Dueck 2006; Flibbert 2006; Ashizawa 2008; Hook 2008; Kitchen 2010).

This study contributes to the constructivist literature by specifying causal mechanisms and contingent conditions for ideational influence on foreign policy. It also bridges material interests in rational models and ideational forces to bring a plausible explanation for foreign policy change. For my empirical investigation of when ideas matter in foreign policymaking, I select the case of the Turkish International Cooperation and Development Agency (TIKA). There is growing interest in explaining Turkey's foreign policy transformation and its increasing visibility in the greater region. TIKA, established in 1992, has considerably expanded the volume and geographic scope of its assistance since 2004. As of 2010, TIKA's 28 program coordination offices operate in 25 countries, covering the Balkans, Central Asia, Africa, and the Middle East (TIKA 2011). Its official development assistance (ODA) exceeded 900 million dollars in 2010, ranking Turkey third among non- Development Assistance Committee (DAC) ${ }^{1}$ countries for that year. Thus, the observed increase in TIKA activities is important to explain policy change.

Several scholars stress systemic changes in international relations, material interests, identity, or changing security discourses as the driving force behind Turkey's foreign policy transformation. The role of ideas and material interests, particularly in constituting its soft power as a foreign instrument, is mostly ignored. This study focuses on whether ideational forces and material interests under the Justice and Development Party (AKP) government have an influence on policy change, and if so, the study attempts to identify causal mechanisms and contingent conditions for how ideas affect Turkish foreign policy.

In the first section, I review the literature around ideas and foreign policy. Then, I discuss alternative explanations of foreign policy change for the selected case study. Next, I describe my theoretical approach and identify causal mechanisms to explain the role of ideas as independent agents of foreign policy change together with material interests within domestic structures. In the second section, I demonstrate the findings in terms of the influence of ideas and material interests in constituting Turkey's soft power via TIKA activities. The third section discusses when ideas matter for foreign policy change. The last section concludes and emphasizes the context-dependent conditions for the influence of ideas on foreign policy.

\section{Ideas and Foreign Policy}

Goldstein and Keohane argue that "ideas define the universe of possibilities for action" (1993:8). They define ideas as "beliefs held by individuals" (1993:3). However, the question of how ideas function as a source for foreign policymaking underlines the premise of ideational forces in explaining foreign policy change.

Risse-Kappen (1994) emphasizes that the change in Soviet foreign policy in the late 1980s was due to a match between the ideas of "new thinkers" in transnational networks and the winning domestic coalitions. The winning coalitions responded, however, differently to those ideas, depending on their domestic structures, which in turn had been determined by political institutions,

\footnotetext{
1 The OECD DAC is an international forum of the world's largest funders of aid. Turkey is not a DAC member but has full observer status. Among non-DAC countries in 2010, Saudi Arabia ranked first (3.48 billion USD), China ranked second (with an estimated 2 billion USD), and Turkey third (967.4 million USD). OECD (2011), Development: Key Tables from OECD, No. 1. doi: 10.1787/aid-oda-table-2011-1-en.
} 
state-society relations, and the values and norms embedded in the state's political culture (Risse-Kappen 1994:186-187).

Dueck (2006) expands a systematic account of classical realism, claiming that the key independent variable of structural realism, namely the distribution of power, has not changed throughout various strategic adjustments of American foreign policy. His findings suggest that distinctive strategic cultures in foreign policymaking are more important than structural changes. Kitchen (2010) also underlines an important deficiency in neorealism, which is ignorance about ideological foreign policy. The author calls his approach "neoclassical" in an attempt "to establish a common intervening variable-the role of strategic ideas"-that combines the structural elements of the international system and domestic and ideational factors of the domestic system for foreign policy analysis (Kitchen 2010:119).

Despite Kitchen's (2010:213) criticism of constructivism that it reduces interests in ideas and ignores material capabilities, I argue that ideas and material interests both matter in constructivist analysis of foreign policy. Constructivism is not only useful to understand the formation of identities, the influence of identities, norms and values on state behavior, and social learning about how actors change their identities and/or diverge in their preferences, but it also contributes to the debate on when ideas and material interests matter.

For example, Flibbert's (2006) study focuses on why the Iraq War was part of US foreign policy. He argues that the ideas of a small group of "policy intellectuals" affected the course of policymaking in terms of its purpose, threat perceptions, and the proper solutions to and political instruments for the core problems, which in turn constituted the American interest in war. He attempts to elaborate on causal mechanisms for when ideas matter in foreign policy and finds that ideas can be causally prior to defining a foreign policy choice. He specifies several hypotheses to explain the contingent conditions for the power of ideas in foreign policy (Flibbert 2006:349-352). His conclusion draws attention to the importance of ideas and material interests in shaping political outcomes. In short, actors constitute their interests depends on mutual constitution of ideas and material interests.

Other empirical studies investigating the role of ideas in foreign policymaking underscore the contingent conditions for ideational influence. For example, Ozkececi-Taner (2005:270) posits that such conditions include the nature of a government (coalition or majority) and characteristics of the actors (or coalition partners) in foreign policymaking. However, the "relevant ministerial position" and the "ministry tak[ing] part in actual policymaking" must coincide with a suggested window of opportunity for the shared normative ideas to have an effect. Ozkececi-Taner (2005) focuses on the impact of "institutionalized ideas" in coalition foreign policymaking with Turkey as a case study. Similarly, Hook's (2008) study emphasizes the importance of "an enabling institutional environment" to embed, and "domestic structures" to filter, principled and causal beliefs as exogenous factors in foreign policymaking.

I apply Goldstein and Keohane's (1993) theoretical approach to ideas as independent agents of foreign policy change to determine the conditions under which they matter in constructing a foreign policy instrument, namely soft power via the selected case of TIKA activities. Ideas shape foreign policy agendas because they are "a condition for reasoned discourse" (Goldstein and Keohane 1993:11). Ideas are conceptualized as principled and causal beliefs in their study. Principled beliefs are normative ideas that determine criteria for understanding what is right or wrong and just or unjust (Goldstein and Keohane 1993:9); in politics, such ideas can translate major principles into policy guidance. Causal beliefs reflect strategies about how to achieve goals, given the normative 
principles that they reflect (Goldstein and Keohane 1993:10). ${ }^{2}$ In other words, causal beliefs help determine which of many means would be used to reach policy goals. However, a strategy is selected when it is appealing according to the principled beliefs, which are essential to evaluate structural environment and to frame problems.

Thus, ideas matter for foreign policymaking when principled and causal beliefs converge and clarify actors' perceptions about how to make policy choices (Goldstein and Keohane 1993:12-13). Such a convergence guides foreign policy by highlighting the causal relationships between the policy goals and political strategies chosen because of compelling ethical or moral motivations for action. Particular policy choices are privileged over others when they are perceived as congruent with shared principled beliefs among foreign policymakers, as well as instrumentally optimal in policy implementation, hence driving causal beliefs.

Nye (2008:95) defines soft power in behavioral terms as attractive power, and in resource terms as the assets that produce such attraction. He emphasizes the importance of hard power for the effectiveness of soft power, that is, "smart power, the ability to combine hard and soft power effectively" (Nye 2008:107). However, for Turkey, the reflexive nature of soft power, as discussed in Bilgin and Elis (2008), is important to understand how foreign policymakers' principled beliefs shape their awareness and understanding of Turkey's self-identification and thus operationalize its soft power. Weber, as discussed in Hall (1993:48), posits that ultimately ideas affect social reality: "Not ideas, but material and ideal interests, directly govern men's conduct. Yet very frequently the 'world images' that have been created by ideas have, like switchmen, determined the tracks along which action has been pushed by the dynamic of interest." Thus, ideas and material interests alike should be considered in the social construction of soft power.

To date, there is no agreement on the causality of ideas in political processes (Yee 1996:71-82; Kitchen 2010:127). Nevertheless, two major features about the role of ideational forces in foreign policy should be noted. First, ideas do not act alone; they need agency to make things happen. Structure and agency, however, cannot be distinguished so it is difficult to identify precise causality about which one dominates the other. Although it can be said that structures and agents are ontologically inseparable, scholars may analytically treat them as if they are distinct (Legro 2000:423). Thus, this study's theoretical approach confirms Marsh's (2009:680) and Kitchen's (2010:128) positions on keeping ideational and material forces separate to analyze how ideas and material interests matter. It differs from Kitchen's (2010) core realist principles, however, which emphasize that the nature of the international system is anarchic and that the major tool of states is power, effectively utilized by material capabilities. Rather, I posit that the extent to which material and ideational factors explain a particular foreign policy outcome is an empirical question. The relationship between ideational and material forces is mutually constitutive. Ideas provide the social context within which agents frame material interests, share norms and values, and practice material capabilities, and they are constrained by the material. Then, agents develop ideas to reinterpret the social context and change those material constraints, and so it continues.

Second, policymakers' intersubjective understanding of a state's self-identity matters in foreign policy analysis. Identities, discourses, norms, and institutions are embedded in historically configured state-society relations (Hopf 2002:

\footnotetext{
${ }^{2}$ Goldstein and Keohane (1993:8) define a third belief: world views, which "are embedded in the symbolism of a culture and deeply affect modes of thought and discourse." In their study, foreign policymakers' world views are assumed because principled beliefs translate world views into guidance for policy choice. Therefore, I assume that foreign policymakers' world views are reflected in their principled beliefs.
} 
278-83). Furthermore, how ideational forces function as a source of foreign policy is dependent on domestic structures (Risse-Kappen 1994; Katzenstein 1996; Hopf 2002). I seek causal connections between ideas and policy outcomes by correlating particular ideas with a particular behavior in a particular policy context. However, I do not ignore the "intersubjective meaning" ${ }^{3}$ of ideas so as to move beyond a limited cognitive approach that emphasizes only an empirical analysis of observable behavior. An empirical investigation can focus on when ideas matter in the foreign policy process in a material world, which shapes and is shaped by human action, and in an interaction with the dynamic normative and epistemic interpretations of material interests in a social context (Adler 1997:332). Thus, Kitchen's (2010:128) criticism, which states that in "defining ideas as beliefs we remove their power," can be responded by constructivism. The convergence of principled and causal beliefs constitutes political practices and politically relevant ideas are not formulated independently of interests and power in a social context.

\section{Alternative Explanations}

Contesting explanations exist in the literature for the Turkish foreign policy transformation since the end of the Cold War. The first group of studies suggests that the major factor driving policy change stems from a change in the international system and states adjusting to the new balance of power in international relations (Karaosmanoglu 2000; Sayari 2000; Larrabee 2010). Sayari (2000:170 176) calls the Turkish foreign policy changes in the Middle East and the Caucasus in the 1990s "assertive activism," a security-driven response to the emerging political instability, war, and ethnic conflict near Turkey's borders. In the Balkans, its policy was explained as "multilateral activism," referencing Turkey's efforts to adjust to changes in the international system. Similarly, Larrabee (2010:158) argues that Turkey's recent activism in foreign policy reflects its efforts to adapt to its changed strategic environment in Turkey's neighborhood after the end of the Cold War. Despite the instability in the Middle East and the Caucasus, the distribution of power or balance of threat has not changed significantly between the 1990s and the 2000s. Accordingly, this first group of studies reveals a neglected dimension: the role of ideational forces in Turkish foreign policy and especially how ideas matter in employing its soft power.

The second group of explanations focuses on domestic politics as a determinant of Turkey's foreign policy transformation. These analyses mostly attribute such changes to "Europeanization," the effects of European Union (EU) conditionality (criteria for the accession process to the EU; Aydin and Acikmese 2007; Ozcan 2008). The impact of EU conditionality on Turkey is underlined in its foreign policy transformation from a "coercive regional power" in the 1990s to a "benign power" in the first decade of the 2000s (Onis 2003). Other studies examine Turkey's domestic political developments (Duran 2006; Altunisik 2009) and its democratization process through the growing influence of interest groups and civil society since 1999 (Rumelili 2005).

Although similar activism in Turkish foreign policy occurred in the 1990s and the first decade of the 2000s, and the same pragmatic reasons to expand Turkish export markets and Turkey's regional power status existed in both decades, the observed difference in TIKA activities in the latter half of the 2000s is puzzling. The amount and means of ODA and the geographic scope of TIKA activities throughout the 2000s increased considerably (Figures 2 and 3). Thus, if strategic calculations driven by changes in the international system or domestic politics

${ }^{3}$ Intersubjective meanings are defined as "the product of the collective self-interpretations and self-definitions of human communities" (Neufeld 1995:77). 
have been in play, I argue that clarifying whether material interests and/or ideational forces contributed to this change is important.

The concept of soft power is widely employed by scholars and politicians to explain the transformation in Turkey's foreign policy (Oguzlu 2007; Altunisik 2008; Onis and Yilmaz 2009:16-18; Kalin 2011). A special issue of Insight Turkey (2008) discusses "Turkey's Rising Soft Power." In this issue, Bilgin and Elis scrutinize Nye's (1990, 2004) soft power concept through critical approaches underlying soft power's reflexive nature, which requires a consideration of "how different actors' needs and wants as well as their understanding of themselves and 'their real interests' are shaped by other actors or by existing structures" (Bilgin and Elis 2008:14). Beng (2008), on the other hand, questions Turkey's ability to exert soft power in its turbulent neighborhood and argues for the need to conceptually clarify Turkey's self-identification and to determine to what extent others legitimize such reification of soft power. Altinay (2008) emphasizes Turkey's potential soft power ability but makes it conditional on the political and foreign policy elites' awareness of it. In light of this discussion and alternative explanations, a theoretical framework to analyze the role of ideational forces in constructing policy change is highly relevant.

\section{Principled and Causal Beliefs and Material Interests in Foreign Policy}

My constructivist analysis incorporates foreign policymakers' ideas as an explanatory variable to posit a plausible explanation for policy change. The dependent variable is policy change, conceptualized in terms of constituting soft power as a foreign policy change and measured in terms of increasing TIKA's ODA by year and region. The convergence of normative principles and political strategies is important to achieve policy change. While principled beliefs define the social purpose of policy change by evaluating the structural environment and framing problems or threats, causal beliefs identify opportunities and prescribe policy in line with material interests (Flibbert 2006:328). Ideas are incorporated analytically prior to interests to deconstruct material interests. Certain beliefs with enough force delimit the sphere of possible political and material interests (Weldes 1999; Wendt 1999). Therefore, the convergence of principled and causal beliefs is set in a dialectical relationship between domestic structures and material interests. Accordingly, the independent variables are ideas and material interests (Figure 1). Domestic structures are "mediating variable" (Hook 2008:152), within which policymakers frame material interests according to principled beliefs, practice material capabilities, and are constrained. Various studies reveal the importance of "leading state officials" (Dueck 2006) or "policy elite" (Checkel 1997; Kaltenthaler 2002) or "a handful of policy intellectuals" (Flibbert 2006) in demonstrating the causal relevance of ideas in a domestic social context. Therefore, foreign policy elite are important to combine

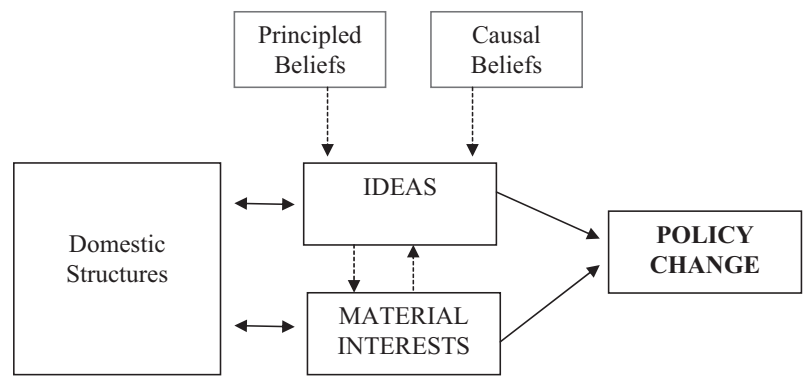

FIG 1. Ideational Influences on Policy Change 
ideational forces into agent-based and materially constrained causal mechanisms. In other words, the policy elite define social purpose, evaluate the structural environment, and frame material interests according to normative principles, which in turn converge with causal beliefs to identify opportunities and prescribe policy instruments. Therefore, in this study, I analyze the following proposition:

Hypothesis: A convergence of principled and causal beliefs reflecting the ideas of a core group of decision makers will constitute soft power as a foreign policy instrument by advancing normative values and material interests in a social context.

\section{Empirical Analysis: Ideational Forces and Change in TIKA Activities}

The TIKA is a unique case to explain the role of ideas and material interests in Turkey's foreign policy change. Turkey's use of soft power through TIKA is important because of bilateral development assistance's nature as an instrument of public diplomacy and foreign policy. I use the methodology of process tracing to examine how ideas matter in foreign policy. While I consider alternative explanations to avoid equifinality, I focus on context-dependent mechanisms to determine empirical explanations rather than generalizable recurring patterns of behavior. Accordingly, I trace the agency's history, particularly of a small group of foreign policymakers, to identify under which conditions their ideas enter into the policy arena and, together with material interests, open a space for ideationally driven change in foreign policy. I collected data from TIKA's annual reports between 1992 and 2010, evaluated articles by senior foreign policymakers and TIKA directors published in different journals, and conducted interviews with TIKA officers. ${ }^{4}$ I trace evidence for the convergence of principled and causal beliefs that match the foreign policy elite's normative ideas presented elsewhere and the particular policy choices made under contingent conditions together with material interests, which in turn resulted in molding TIKA activities as an instrument of soft power throughout that time period.

\section{Change in TIKA Activities}

Turkish assistance to foreign countries began after its contribution to the UN's multilateral technical assistance program in $1957 .{ }^{5}$ Turkey's early bilateral assistance was limited in amount and geographic scope. In 1992, an agency to plan, coordinate, and implement development assistance was established in the aftermath of the dissolution of the Soviet Union and the consequent changes in the immediate environment of Turkish foreign policy. In 2001, it was renamed as the TIKA and restructured under the supervision of the Prime Ministry (Parlak 2007:129-130).

Changes in TIKA activities can be summarized into three major periods: (i) the early period, from its establishment in 1992 till May 2001 (when its administrative status changed); (ii) the transition period, from 2001 till 2004 (when Turkey's development assistance was harmonized with the DAC's rules of classification and reporting); and (iii) the late period, from 2004 until 2010. The late period is puzzling because there is a significant change in the volume and

\footnotetext{
${ }^{4}$ I kept the names of interviewees anonymous and referred to them by numbers because they are government officials and required to have permission from the head of their organization to give an interview that might be published. I intentionally avoided this official procedure to facilitate an environment of trust and flexibility for the interviewees so that they would feel no hesitation for any bureaucratic reason.

${ }^{5}$ Turkey's bilateral technical assistance was first offered to Iran and Pakistan in 1971 according to Central Treaty Organization (CENTO) and Regional Cooperation for Development agreements.
} 


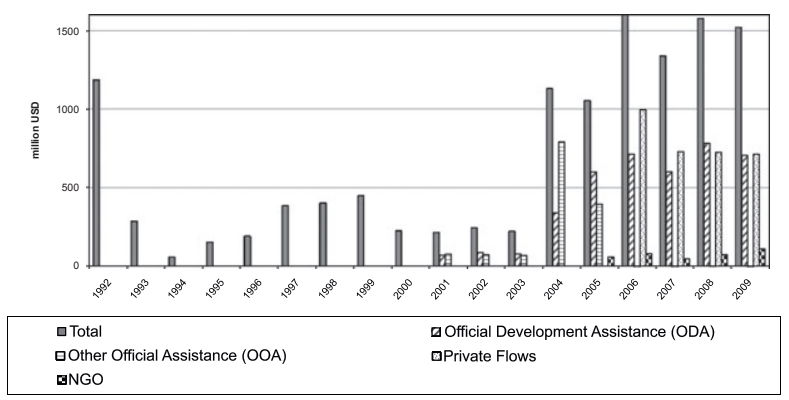

FIG 2. Turkey's Total Development Assistance. Source: Turkish International Cooperation and Development Agency, TIKA Annual Reports 2004-2010 and Parlak (2007:74 and 79)

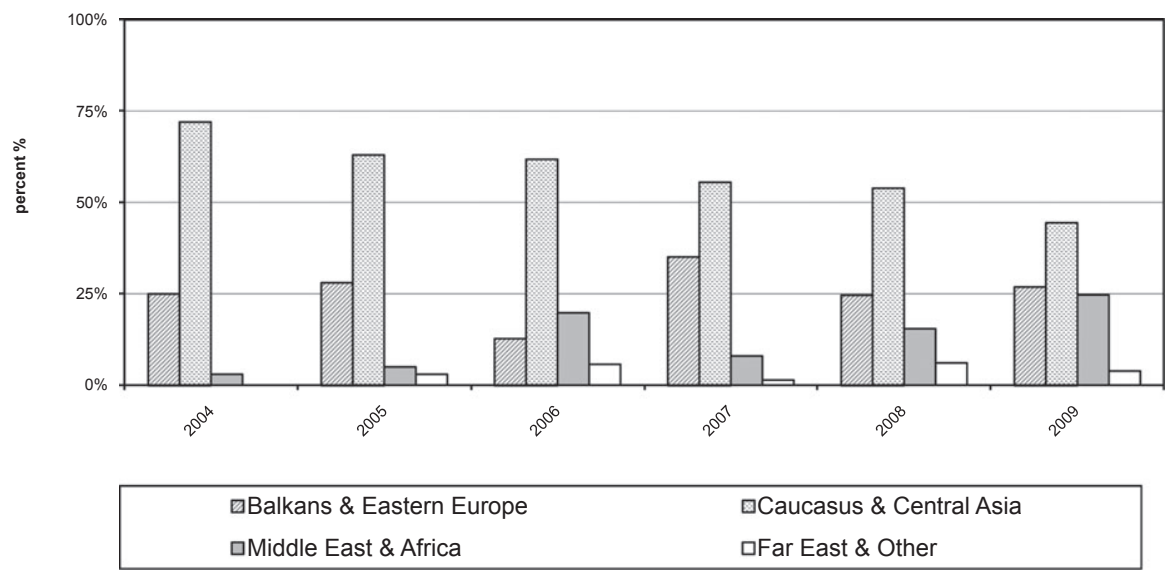

Fig 3. Turkey's Total Development Assistance by Regions. Source: Turkish International Cooperation and Development Agency, TIKA Annual Reports 2004-2010

means of TIKA's ODA and in its geographic scope (Parlak 2007; TIKA Annual Reports 2004-2010; see Figures 2 and 3). For example, between 1992 and 1996, the Central Asia-Caucasus region had the highest share of Turkey's total ODA $(86.5 \%)$. Between 1997 and 2003, the amount declined to $40 \%$ of that because of the shift in focus to reconstruction and humanitarian efforts in the BalkansEastern Europe region after the ethnic wars in Bosnia and Kosovo (1993-1995 and 1998-1999, respectively; Parlak 2007:74,79). Economic interests in energy resources, pipeline projects in the Central Asia-Caucasus region, and the ethnic conflict in the Balkans threatening Turkey's trade relations were major issues shaping TIKA's agenda in the 1990s. Nevertheless, Turkey's ODA declined sharply in 1992 and remained relatively low until 2004 because of major economic crises in the 1990s and 2001.

Most of TIKA's ODA since 2001 has continued to focus on the Central AsiaCaucasus and the Balkans-Eastern Europe regions, although since 2004 an increasing share has been allotted to the Middle East and Africa regions (see Figure 3). Accordingly, the change in TIKA activities by region and amount of ODA could be attributed to (i) a change in Turkey's material capabilities because of a change in the international system and geopolitics after the end of the Cold War or (ii) a change in domestic politics and economic interests, as discussed in alternative explanations above. However, the first argument emphasizes 
change in the international system as a parsimonious explanation for foreign policy change, and it does not explain the change in TIKA activities between 1992-2001 and 2004-2010, when there was no change in the international system or the balance of power. The second argument neglects the role of ideational forces and includes a limited account of rationally calculated material interests. Conversely, I propose that the convergence of principled and causal beliefs of Turkey's new foreign policy elite appears to be the driving force behind the change in TIKA activities, advancing normative values and material interests to translate ideas and strategies into policy change.

\section{Principled Beliefs and the Foreign Policy Elite}

The AKP majority government was elected in Turkey in 2002 following a period of coalition governments from 1991 to 2002, and it subsequently appointed new foreign policymakers. The principled beliefs of a small group policy intellectuals or foreign policy elite are detailed in Strategic Depth (2001), written by Ahmet Davutoglu, current minister of foreign affairs. His ideas are largely shared by his colleagues, as evident in their own writings (Fidan and Nurdun 2008; Aras and Fidan 2009; Kalin 2011). The AKP foreign policy elite consists of (i) Davutoglu, chief advisor on foreign affairs to Turkey's prime minister between 2003 and 2009 and current minister of foreign affairs since 2009; (ii) Hakan Fidan, president of TIKA between 2003 and 2006, deputy undersecretary of the Prime Minister's Office between 2006 and 2009, deputy head of the National Intelligence Service in 2009 and 2010, and current head of the National Intelligence Service; and (iii) Ibrahim Kalin, chief advisor on foreign affairs to the prime minister since 2009.

Davutoglu's conceptualizations of Turkey's "historical and geographic depth" Davutoglu (2008:78-79) summarize the core of his normative ideas. Historical and geographic depth focus on a country's past, present, and future relations, which are argued to be built on geocultural, geopolitical, and geoeconomic factors at the domestic, regional, and global levels. His cohesive formulation of strategic depth envisioned through these historical and geographic dimensions frames his normative ideas about how soft power and a new vision for Turkey's foreign policy can be constructed. For example, he underlines the five operational principles (built on the principled beliefs defined in Strategic Depth (2001)) and three methodological principles (casual beliefs) in the new foreign policy. ${ }^{6} \mathrm{He}$ defines the latter as (i) "a 'visionary' approach to the issues instead of the 'crisis-oriented' attitude that dominated foreign policy during the entire Cold War period"; (ii) a policy based on "a 'consistent and systematic' framework around the world"; and (iii) "the adoption of a new discourse and diplomatic style, which has resulted in the spread of Turkish soft power in the region" (Davutoglu 2010).

Davutoglu's principled beliefs are shared and supported by a small group of foreign policy elite and define social purpose, evaluate the structural environment, and frame problems in devising strategies for his foreign policy vision. Aras and Fidan (2009:197) link the change in Turkish foreign policy to the "reconstruction of the previous geographic imagination in policy-making circles". While the authors acknowledge the importance of strategic calculations and material interests in the Eurasia region for Turkish foreign policymakers since the dissolution of the Soviet Union, their argument asserts that the "new geographical imagination gave rise to novel interpretations of the Eurasian region in the minds of foreign policymakers" (Aras and Fidan 2009:199). Similarly,

6 The operational principles consist of security and democracy, zero problems with neighbors, proactive and preemptive peace diplomacy, a multidimensional foreign policy, and rhythmic diplomacy. 
Kalin attributes the new geographic imagination as "a new idea of time and place [that] makes it possible for Turkey to produce its own concepts and build a new vocabulary." He ascribes the change to "a profound mental transformation," praising Davutoglu's work and policy as a narrative effort to see the world from a non-Eurocentric perspective (Kalin 2011:6-7). In short, the principled beliefs are translated into foreign policy goals reflecting ethical values based on a broader narrative of the history and culture of Eurasia together with material interests in a social context.

\section{A Convergence of Principled and Causal Beliefs Constituting Policy Guidance}

The convergence of principled and causal beliefs was essential for policy change. The principled beliefs defined the social purpose of foreign policy by framing Turkey's role in historic, cultural, and geographic terms, and the causal beliefs prescribed "a new discourse and style in spreading soft power" (Davutoglu 2010). In fact, Davutoglu (2012:5-7) endorses the principles of Turkish foreign policy by highlighting Turkey's quest to pursue a "value-based foreign policy" while defending national interests in the aftermath of the uprisings in the Middle East and North Africa that began in 2010. He notes how Turkish foreign policy is shaped by major normative principles and political strategies such as "reintegrat[ing] with its neighbors" and its "ongoing process of reconnecting with the people in [its] region with whom [it shares] a common history and [is] poised to have a common destiny" (Davutoglu 2012:3-4). He suggests that as Turkey positions itself with the historic political transformation in its region, it "requires new instruments which might be missing in Turkey's traditional foreign policy toolkit" and underlines "active involvement in new areas such as international development assistance" (Davutoglu 2012:5-6). Thus, the foreign policy elite's emphasis in discourse on soft power and the instruments of foreign policy represent means about how shared normative ideas can produce a particular end.

Since 2004, TIKA's annual reports have demonstrated the influence such ideational forces have had on TIKA activities as an instrument of soft power. Full and uninterrupted coordination between TIKA and the ministry of foreign affairs, promoting TIKA activities as public diplomacy, and prioritizing projects that increase Turkey's visibility in ODA recipient countries have been highlighted as operational principles (TIKA 2006:3). These principles implicitly emphasize the convergence of shared principled beliefs and causal beliefs in constituting a foreign policy change, namely employing soft power via TIKA activities. Former Minister of State Besir Atalay, responsible for TIKA, boldly stated its new role in foreign policy: "Our government has an awareness of how important ODA is in foreign policy" (TIKA 2006:iv). The Turkish government declared 2005 as "the year of Africa in Turkey," and TIKA opened offices there for the first time. Offices and projects in the Middle East were also prioritized in line with the new thinking in foreign policy (TIKA 2007:2). In 2008, former Minister of State Mustafa Said Yazicioglu elucidated TIKA's role in Turkey's soft power initiatives: "TIKA has assumed responsibility for turning the increasing number of commitments made by the government of Turkey towards SubSaharan African countries, Afghanistan, Palestine and Iraq, etc. into concrete projects" (TIKA 2008:5). Musa Kulaklikaya, TIKA's former president, stated:

As a natural extension of the multi-faceted foreign policy that is effective in all regions and reconciles the East with the West, and the North with the South, Turkey, which is an active member of the current global community, is increasingly supporting this global phase by increasing...the effectiveness of TIKA in the area of development cooperation (TIKA 2008:7). 
And:

TIKA's development assistance projects implemented in partnership with the Republic of Turkey's Ministry of Foreign Affairs have played an important role in securing non-permanent member status for Turkey with an extremely high rate of 151 out of 192 country votes in the first round at the UN Security Council, and as such, TIKA has befittingly executed its responsibility within the priorities of foreign policy (TIKA 2009:3).

The convergence of principled beliefs and causal beliefs affect foreign policy under specific conditions. An opportunity created by a major change in domestic politics (the majority government of the AKP after a decade of coalition governments in Turkey) was crucial to facilitate support from key decision makers and to allocate the required level of resource commitment. Thus, while the principled beliefs of the foreign policy elite interpreted the structural and discursive context embedded in domestic structures to constitute soft power, their causal beliefs prescribed policies to transform normative values and material interests into soft power via TIKA's activities.

Top-level bureaucrats at TIKA confirm such a transformation, stressing that "a new foreign policy vision pursued by the current government played a major role in the expansion of ODA" (Kulaklikaya and Nurdun 2010:139). Further,

during the Turgut Ozal government between 1983 and 1989 there was also foreign policy activism; however, an agency to plan, coordinate and implement Turkey's development assistance was established in 1992. TIKA's potential could not be utilized through the 1990s. In 1999, when there was a coalition government, the Nationalist Movement Party recognized the importance of TIKA, given its ideological and political interests in the Central Asia-Caucasus region. Therefore, TIKA was restructured as an independent organization under the prime ministry in 2001, but the coalition government was short lived. It was after the majority government of AKP in 2003 that a vision of foreign policy was enacted in which TIKA had a role from the beginning. Mr. Davutoglu and Mr. Fidan worked closely together to transform TIKA activities into instruments of soft power. ${ }^{7}$

Other officers at TIKA confirmed the convergence of principled and causal beliefs observed during close cooperation between Fidan and Davutoglu in expanding TIKA activities to new regions. Davutoglu held many meetings at TIKA, sharing his foreign policy vision and explaining how TIKA activities would be supplementary to Turkey's soft power efforts. ${ }^{8}$ Thus, these meetings were important to disseminate the shared normative ideas of the foreign policy elite and the corresponding strategies to shape TIKA activities for policy change. Further, one project coordinator noted that

[t] he change in TIKA activities is not conjectural; we closed our eyes to Africa and the Middle East in the 1990s. For example, the founding legislation of 1992, which established TIKA, starts with the phrase "the Turkish republics and the fraternal communities," limiting and reflecting the priorities to a regional focus. This phrase is replaced only later to cover "all developing countries." The understanding has changed since Mr. Fidan at TIKA and Mr. Davutoglu at the prime ministry have worked closely. The government and the politicians supported this new vision because they want outcomes. In comparison, the ambassadors have been more cautious and most of them did not have a shared understanding of the role of TIKA. However, TIKA and the ministry of foreign affairs started to share a common agenda with the AKP government in time. Some ambassadors familiar with TIKA

\footnotetext{
7 Author's interview with a senior director at TIKA on March 9, 2012 in Ankara.

8 Author's interviews with project coordinators \#1, \#2, and \#3, and other officers at TIKA on March 9, 2012 in
} Ankara. 
supported regional expansion into the Middle East; for example, in Iraq. Now ambassadors call us and inform us about the need for TIKA projects. ${ }^{9}$

One officer considered the "cooperation between Davutoglu and Fidan as a chance for TIKA [to translate shared principled beliefs into policy guidance] because they share the same vision." ${ }^{10}$ Similarly, other project coordinators emphasized the political outcomes of TIKA activities on soft power and foreign policy:

\begin{abstract}
It appears that we build bridges or drill water wells to provide simple technical assistance. However, we have a good understanding of and share a similar culture with the people in the field and this allows close relationships in the region both at the government level and at the civil society level. The new foreign policy vision understood this potential. Wherever the prime minister or foreign minister visits in the Middle East, or Africa, or the Balkans, there will be an opening ceremony for a facility built by TIKA's ODA. ${ }^{11}$
\end{abstract}

And:

Now people in Africa call us "their white men." The visibility of TIKA has increased tremendously. There is great sympathy from the people in these regions to TIKA, and so too to Turkey. ${ }^{12}$

In summary, the above examples illustrate that the convergence of principled and causal beliefs under the leadership of the foreign policy elite is causally prior to explaining policy change together with material interests, which is discussed in the next subsection. Ideas matter in foreign policy when normative values (defining social purpose, evaluating material constraints, framing problems) and political strategies (identifying opportunities, prescribing specific choices, securing required resources) converge within the context of domestic structures and material interests. Accordingly, a set of contingent conditions is important to turn a core group of foreign policy elite's ideas into strategies that result in policy change. In the Turkish case, the conditions were the majority government of the AKP and the foreign policy elite's access to key decision makers, particularly Prime Minister Erdogan.

\title{
Material Interests and TIKA Activities
}

Turkish International Cooperation and Development Agency has been regularly publishing reports on total development assistance according to the classification rules determined by the DAC since 2004. ${ }^{13}$ Total development assistance includes ODA, other official assistance, private flows, and support to NGOs. Accordingly, there are four new reporting areas for ODA: private flows (direct investment made by Turkish entrepreneurs in developing countries), Turkish peacebuilding activities, expenditures for refugees, and contributions to the Millennium Development Goals (TIKA 2007; Fidan and Nurdun 2008:98-101). In fact, Turkey's recent significant economic growth, increased trade with and investment volume in all neighboring countries, and improved relations with

\footnotetext{
9 Author's interview with project coordinator \#1 at TIKA on March 9, 2012 in Ankara.

${ }^{10}$ Author's interview with an officer at TIKA on March 9, 2012 in Ankara.

${ }^{11}$ Author's interview with project coordinator \#2 at TIKA on March 9, 2012 in Ankara.

${ }^{12}$ Author's interview with project coordinator \#1 at TIKA on March 9, 2012 in Ankara.

13 Between 1992 and 1996, the State Planning Organization classified Turkey's development assistance into four groups: (i) technical assistance, (ii) humanitarian aid, (iii) economic aid and cooperation, and (iv) cultural and scientific cooperation. However, Turkey's contribution to multilateral development agencies was not accounted for, and there was no separation between donations and loans. Between 1997 and 2002, the State Statistics Institute, on the other hand, considered Turkey's total development assistance as donations, ODA, and multilateral development assistance.
} 
Greece, Iraq, and Syria in the 2000s have been credited to its apparent ability to increase foreign policy activism between Eurasia and Europe during the AKP era (Onis and Yilmaz 2009:19). Thus, the importance of material interests should not be ignored. As discussed in the theoretical framework of this study, the convergence of principled and causal beliefs do not occur in a vacuum. Ideas provide the social context within which the foreign policy elite share principled beliefs, frame material interests, and practice material capabilities, and they are constrained by the material world. Ideational forces are important to reinterpret the social context and change the material constraints of foreign policy.

Kirisci (2009) explains the relationship between economic factors and foreign policy through the concepts of the "trading state" and "two-level diplomatic games." For example, the "zero problems with neighbors" principle in foreign policy becomes vital in diplomatic negotiations and in promoting economic interests because the trading state interacts with a wide range of actors in national constituencies for foreign policymaking. Kirisci argues that the zeroproblems policy can be considered "a blue-print manifestation of the foreign policy of a trading state" (Kirisci 2009:42); nevertheless, he acknowledges that none of the principles in Davutoglu's foreign policy makes direct reference to economic interests. Kirisci introduces the concept of interdependence functioning as a market-seeking instrument in addition to using conflict-resolution and peacebuilding tools to explain how a trading state advocates foreign policy activism. He compares Turkey's current foreign policy activism with the Ozal government's liberal market policies of the 1980s and concludes that the latter led to the emergence of strong business interest groups that initiated Turkey's rise as a trading state in the 2000s, thus shaping its foreign policy activism.

Despite Kirisci's argument, business interest groups' priorities in terms of trade expansion by region changed in the 2000s. A closer examination of Turkey's export and import orientation by region from 1990 to 2010 demonstrates that penetration into the Middle East and Africa regions only began after 2003. Since the Customs Union Agreement in 1995, Turkey's trade with the EU has increased steadily. Although the EU countries continue to be Turkey's major export market, Turkey has a large trade deficit with the EU and a trade surplus with the Middle East and Africa (see Figures 4 and 5). In other words, trade relations with the Middle East and Africa were insignificant through the 1990s but have become important because of Turkey's increasing trade surplus with them since 2003.

A comparison of exports by region between two eras, 1990-2001 and 20022010, highlights the rapid increase in exports to the Middle East and Africa during the latter period, since the AKP government has been in power. ${ }^{14}$ Moreover, while the EU's share in Turkey's total exports has declined from $63.1 \%$ in 2002 to $49.5 \%$ in 2010, the Middle East's share has increased from $10.5 \%$ in 2002 to $21.8 \%$ in 2010. While the share of exports to Africa is relatively smaller in total exports $(6.6 \%$ in 2010), exports to Africa have increased considerably. Between 2002 and 2010, the exports to the Middle East and Africa have increased $77.5 \%$ and $74.7 \%$, respectively. Thus, the Middle East and Africa have the highest increase in exports compared to other regions. Accordingly, while market openings in the CIS after the dissolution of the Soviet Union played a role in increasing exports to that region between 1990 and 2001, the significant increase in

\footnotetext{
${ }^{14}$ For example, the EU was the largest export market for Turkey in both eras. However, the increase in exports to the EU was $167 \%$ between 1990 and 2001 and $158 \%$ between 2002 and 2010. On the other hand, the highest increase in exports was to the Commonwealth of Independent States (CIS) countries between 1990 and 2001 $(273 \%)$ and the Middle East between 2002 and 2010 (578\%). The second- and third-ranked regions in terms of export increases are the United States and the EU between 1990 and 2001, and Africa and the CIS between 2002 and 2010.
} 


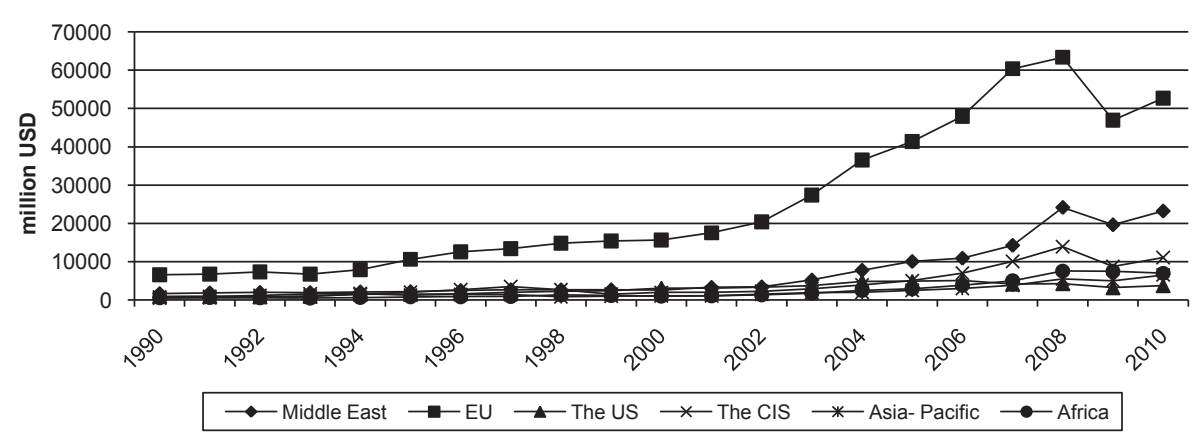

FIG 4. Turkey's Exports by Regions, 1990-2010. Source: Ministry of Economy, Trade Statistics by Countries

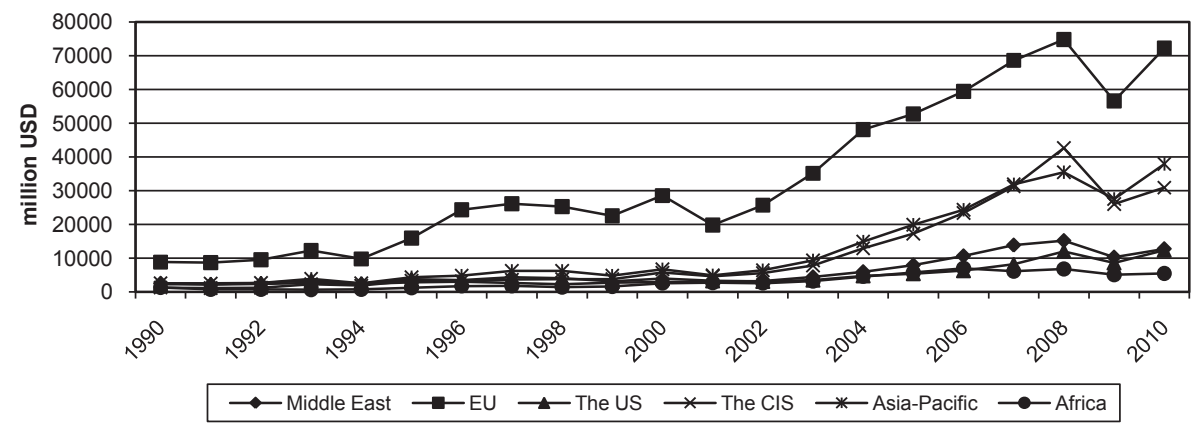

FIG 5. Turkey's Imports by Regions, 1990-2010. Source: Ministry of Economy, Trade Statistics by Countries

exports to the Middle East and Africa between 2002 and 2010 requires further examination. Therefore, I analyze the relationship between ideational forces and material interests within the context of domestic structures in explaining the change in TIKA activities.

Although Turkey's trade relations have been a factor in foreign policymaking since the end of its import substitution policy and the beginning of export-led growth model in the 1980s, the turning point for policy change was the convergence of strategies to advance normative values and material interests according to the principled beliefs embedded in the new foreign policy vision under the AKP government. Those beliefs defined the social purpose and implicitly legitimized the criteria for expansion into new markets in "an integrated foreign policy" approach. For example, Foreign Minister Davutoglu's so-called new foreign policy kit (Davutoglu 2012:5) and methodological principles (causal beliefs; Davutoglu 2010) have reshaped state and societal actors' material interests and allowed them to benefit from those ideas. Similarly, Kalin (2011:8), chief foreign policy advisor to the prime minister, considers "Turkey's soft power different from that of other countries in its form and content" because of "the cultural and historical experience it inherited". He does acknowledge, however, that "Turkey's achievement of an effective soft power status depends on its ability to mobilize these dynamics" (Kalin 2011:10-11). The expanded volume and geographic scope of TIKA activities since 2004, therefore, serve to constitute Turkey's soft power and transform the material constraints of Turkish foreign policy. 
The role of societal actors in supporting specific causal beliefs is important to understand the relationship between the ideational forces and material interests influencing a foreign policy change. ${ }^{15}$ Through the integration of business organizations and think tanks, Aras and Fidan consider civil society's input into the foreign policy-making process part of "the new geographical imagination in policymaking circles" (2009:198). Moreover, Davutoglu (1994) has explicitly acknowledged the business community as a central driver in foreign policy. The emergence of a new business class (the "Anatolian Tigers") in Anatolia's major industrial cities also indicates support for the change in foreign policy (Hale 2000; Ayata 2004; Vardan 2010; Atli 2011:116). Omer Cihan Vardan, president of the Independent Industrialists and Businessmen's Association (MUSIAD; essentially the business association for the Anatolian Tigers) states that

[when the] AKP came to power with a majority in 2002, it was the starting point for Turkey, [bringing] greater value in different aspects. ... [Through] the correct political choices made by the ruling party [to gain] internal economic and political stability, Turkey has obtained the identity of being a rising star in international arenas in recent years. ... We should always keep in mind the fact that domestic and foreign policy are attached to each other with steel ropes (Vardan 2010:9).

Thus, as the Anatolian Tigers increasingly conduct business in new regions, they seek a new dynamism to support Turkey's export potential. ${ }^{16}$ Vardan clearly expressed this demand of the business community and praised the new foreign policy activism by implicitly underlining the convergence of principled and causal beliefs under the AKP government, in which the material interests of societal actors also benefited.

... [T] here was the need to convert this potential to "kinetic" by using the right political methodology and tools. Creating Turkey's economic stability and [correctly managing its] foreign policy [has contributed to its rise].

... [T] he reality that we mentioned above has been put forward by Prof. Ahmet Davutoglu in his work called Strategic Depth and he did not only make an intellectual and academic contribution by this, but also, firstly as the foreign policy advisor to the Prime Minister and the Minister of Foreign Affairs and then as the Foreign Minister himself, he implemented the ideas that he asserted. It is essential that these ideas are accepted and appreciated especially by his Excellency our President Mr. Abdullah Gul and our Prime Minister Mr. Recep Tayyip Erdogan, and their dedicated team (Vardan 2010:11).

In Turkey's domestic politics, then, the shared principled and causal beliefs of the foreign policy elite are not formulated independently of interest and power. Legitimizing political and economic practices, TIKA's expansion into the Middle East and Africa can be considered a function of ideas, shifting the focus to Turkey's soft power activities, and reinterpreting material constraints in foreign policy. Kalin (2011:7) emphasizes the merger between "the new geopolitical imagination" and Turkey's economic and security priorities, and states that

\footnotetext{
15 Since 2007, TIKA has increased its support to Turkish NGOs operating abroad, and in 2009 founded its Cooperation and Coordination Unit to institutionalize NGO activities.

16 Turkey can increase its exports by $30 \%$ under current conditions, and the Middle East is a major market in terms of demand for a wide spectrum of Turkey's competitive export products compared to other regions (Dis Ticaret Mustesarligi (Undersecretariat of Foreign Trade) 2011).
} 
[T] he business interests and increased economic profile of the country [are] indicators of Turkey's increasing capacity for soft power. [There is] a promise to push for a more active foreign policy, because it is necessitated by our history, geography, a very active NGO community, and the business community. ${ }^{17}$

Similarly, Davutoglu (2010) frames Turkey's new foreign policy principles as "a new language in regional and international politics that prioritizes Turkey's civileconomic power". An officer at TIKA explained Turkey's role of soft power in serving the business community's material interests:

TIKA activities increase the visibility of Turkey and establish people's trust in Turkey. Thus, when Turkish entrepreneurs enter into the new markets of the Middle East and Africa, they benefit from this trust and sympathy. ${ }^{18}$

Likewise, a senior director clarified TIKA's role in Turkish business:

Turkish businessmen follow TIKA in the Africa region. When TIKA opens up an office in one African country, Turkish Airlines starts flights to these destinations, which increases the interest of businessmen and simplifies their operations. For example, in Ethiopia and Somalia you can observe such a pattern. ${ }^{19}$

While the question of whether or not there is congruence between specific TIKA activities in countries and the strategic interests of state officers and societal actors is beyond the scope of this study, it can be concluded that the expansion of TIKA into the Middle East and Africa has been accompanied by the rapid increase in exports there, particularly between 2002 and 2010. Consequently, the change in TIKA is driven by the convergence of principled and causal beliefs, which define social purpose, identify opportunities, frame material interests, and prescribe political choices regarding soft power in foreign policy, and these choices are made in conjunction with societal actors' material interests.

\section{Discussion: When Ideas Matter}

The case of TIKA reveals important evidence regarding the conditions under which ideas matter in foreign policy. Ideas usually exist plurally in a given setting, and how precisely they function as a source for foreign policy change can be analyzed through the type and composition of actors, material interests, and the role of domestic structures.

Within this framework, having a core group of foreign policymakers is important. Placing TIKA under the prime ministry after 2001 facilitated a convenient environment for TIKA's president, the chief advisor of foreign affairs, and the cabinet to work together. However, although the convergence of principled and causal beliefs reflecting ideas as exogenous to the foreign policy process is essential, it is also contingent on particular conditions. The importance of normative values and material interests was emphasized in Davutoglu's foreign policy vision long before he was appointed chief advisor on foreign affairs in the AKP government (Davutoglu 1994). However, these ideas did not formally enter the policy arena until 2003. Since 2003, the AKP empowered Davutoglu and a team of policy intellectuals, which in turn opened a window of opportunity for foreign policy change. The confidence and trust bestowed on

\footnotetext{
17 Quoted from Kalin's speech titled "Recent Developments in Turkish Foreign Policy: An Assessment" and presented at the Insight Turkey Annual Conference: "Debating New Turkey" organized by the SETA Foundation on December 3, 2010 in Washington, DC. http://setadc.org/component/content/article/34-spotlight/301-debatingnew-turkey, accessed September 2012.

18 Author's interview with project coordinator \#3 at TIKA on March 9, 2012 in Ankara.

19 Author's interview with a senior director at TIKA on March 9, 2012 in Ankara.
} 
Davutoglu by Prime Minister Erdogan was evident in his appointment to the ministry of foreign affairs as a nonelected cabinet member in May 2009. Thus, a change in political leadership and a majority government facilitated a match between the ideas of "policy intellectuals" and political actors and paved the way for an interaction with the material interests of societal actors. Ozkececi-Taner (2005) focuses on "institutionalized ideas"; her findings suggest that political actors are crucial agents to transfer ideas into foreign policymaking. She emphasizes the previous "battle of ideas" in Turkish foreign policymaking between political parties in the coalition governments from 1991 to 2002. The findings in this study complement the importance of "institutionalized ideas" and highlight the two conditions that affected the influence of a small group of policymakers' ideas on foreign policy in Turkey.

Accordingly, while pioneering studies on the role of ideas and norms in international relations focus on how policy networks or epistemic communities at the transnational level impact norm transfer or social learning, which thus alters foreign policymaking at the domestic level (Haas 1992; Risse-Kappen 1994; Risse and Sikkink 1999; Schemmelfennig 2001; Finnemore 2003), this study reemphasizes the importance of domestic ideas in foreign policy as demonstrated in other studies (Kaltenthaler 2002; Quaglia 2004; Flibbert 2006). Furthermore, elite policy intellectuals, with their unconstrained access to political authority are observed as significant agents in the mutual constitution of normative values and material interests in foreign policy (Flibbert 2006).

On the other hand, foreign policy change cannot be adequately explained without reference to domestic structures. Policymakers' intersubjective understandings of a state's identity, as well as discourses, norms, and institutions, are embedded in domestic structures (Risse-Kappen 1994; Katzenstein 1996; Hopf 2002). Domestic structures vary across nations, and social facts are understood differently across divergent social contexts. Thus, ideational forces constituting soft power in Turkey's foreign policy have also been filtered through domestic structures.

For example, Davutoglu's overall policy prescription is constituted around conceptualizing a state identity first regionally, then globally, in coordination with intrastate cultural, political, and economic parameters in addition to the geopolitical and geoeconomic advantages a country inherits (Davutoglu 2001). Kalin (2011) similarly maintains that Turkey's new identity reconciles its cultural and historical inheritance in its soft power and comprehensively communicates it in its public diplomacy activities. Therefore, the foreign policy elite's self-identification, particularly in Turkey's historically configured statesociety relations and the extent of state autonomy from society in a parliamentary political system, requires further research on how ideational forces filter through domestic structures. For example, Hook's (2008) study reveals the importance of sharing the executive and legislative powers in the American presidential regime and the policy impact of societal actors' material interests in its domestic structures. Thus, intersubjective understanding of state identity by the foreign policy elite should be assessed cautiously and explored as "having [the] resources to deploy discursive power" in foreign policy (Hopf 1998:179). The findings in this study reveal that ideational and material forces are both in play during the foreign policy elite's constitution of policy change.

Last, an external shock is considered as important to create a window of opportunity for policy entrepreneurship, which allows the influence of ideas in foreign policy in other research studies (Flibbert 2006). However, foreign policy change in the case of TIKA activities is observed in the absence of an external shock or a security crisis. 
This study's findings confirm the importance of context-dependent conditionality for ideational influence. A recognized foreign policy elite, unconstrained access of foreign policy intellectuals to decision makers, and an enabling political environment are specific conditions to assess when ideas and material interests of societal actors interacting within the social context of domestic structures matter in foreign policy. Consequently, while it is clear that the specific conditions discussed above are necessary for ideational influence on foreign policy, it is difficult to conclude whether they are sufficient. For Turkey, other cases under the AKP government and the previous coalition governments should be examined to determine their explanatory power in foreign policymaking.

\section{Conclusion}

This study examined the role of ideas in foreign policy change and attempted to identify how ideas function as a source for foreign policymakers. The findings confirm the suggested constructivist account for policy change that emphasizes not only ideas but also material interests as exogenous factors constituted within domestic structures. My empirical analysis in the case of TIKA reveals important evidence demonstrating the influence of (i) shared normative values, mostly constituted by the foreign policy elite's intersubjective understanding of Turkey's historical roots and cultural ties in the region and (ii) material interests, favored through the "trading state" and framed by the convergence of principled and causal beliefs on policy change. The findings suggest that Turkey's foreign policy activism since the 2000s cannot adequately be explained without referencing the convergence of specific principled and causal beliefs, which defined social purpose, evaluated the structural environment, and framed material interests, limiting certain foreign policy choices and legitimizing others in constituting policy change.

Although Turkey engaged in similar foreign policy activism in the 1990s and the early 2000s, and had similar material interests in expanding its export markets and regional power status in both decades, the significant increase in TIKA activities in the latter decade can be attributed to the influence of ideational forces and material interests. The turning point for policy change was the convergence of strategies to advance material interests and normative ideas in determining the criteria for constituting soft power as an instrument of foreign policy, a factor that was missing in the previous period. Incorporating business organizations, think tanks, and civil society's ideas and expectations into the foreign policy-making process is a function of using ideas to identify strategies to serve principled beliefs and material interests, as well as legitimize political practices.

From the findings, I conclude that ideas matter in foreign policymaking when a set of contingent conditions is satisfied: (i) A small group of recognized foreign policy elite has shared normative beliefs and (ii) an enabling political environment exists, particularly a majority government facilitating foreign policy appointments to key positions so that a window of opportunity is provided for policy entrepreneurship. This single case study is empirically limited, but it is suggestive of broader patterns of policy change.

The interaction between social structures and agents of change is difficult to assess empirically; however, the type and composition of the involved actors and the institutional environment seem to define the contingent conditions for how and when ideas matter. Foreign policy choices are made not only with future results in mind, but are also informed by normative concerns about how choices should be made. In light of the empirical analysis and discussion illustrated above, it can be argued that the logic of appropriateness and the logic of 
consequences have both played a part in the behavior of Turkey's foreign policy elite. Still, the context-dependent conditions for the influence of ideational forces require further research to determine how they play out in other states and issue areas.

\section{References}

Adler, Emanuel. (1997) Seizing the Middle Ground: Constructivism in World Politics. European Journal of International Relations 3: 319-363.

Adler, Emanuel. (2002) Constructivism and International Relations. In Handbook of International Relations, edited by Walter Carlsnaes, Thomas Risse and Beth A. Simmons. Beverly Hills: Sage.

Altinay, Hakan. (2008) Turkey's Soft Power: An Unpolished Gem or an Elusive Mirage? Insight Turkey 10: $55-66$.

Altunisik, Meliha. (2008) The Possibilities and Limits of Turkey's Soft Power in the Middle East. Insight Turkey 10: 41-54.

Altunisik, Meliha. (2009) Worldviews and Turkish Foreign Policy in the Middle East. New Perspectives on Turkey 40: 169-192.

Aras, Bulent, and Hakan Fidan. (2009) Turkey and Eurasia: Frontiers of a New Geographic Imagination. New Perspectives on Turkey 40: 195-217.

Ashizawa, Kuniko. (2008) When Identity Matters: State Identity, Regional Institution Building, and Japanese Foreign Policy. International Studies Review 10: 571-598.

Atli, Altay. (2011) Businessman as Diplomats: The Role of Business Associations in Turkey's Foreign Economic Policy. Insight Turkey 13: 109-128.

Ayata, Sencer. (2004) Changes in Domestic Politics and the Foreign Policy Orientation of AK Party. In The Future of Turkish Foreign Policy, edited by Dimitris Kerides and Lenore Martin. Cambridge: MIT Press.

Aydin, Mustafa, and Sinem Acikmese. (2007) Europeanization Through EU Conditionality: Understanding the New Era in Turkish Foreign Policy. Journal of Southeastern European and Black Sea Studies 9: 263-274.

Beng, Phar Kim. (2008) Turkey's Potential as a Soft Power: A Call for Conceptual Clarity. Insight Turkey 10: 21-40.

Bilgin, Pinar, and Berivan Elis. (2008) Hard Power, Soft Power: Toward a More Realistic Power Analysis. Insight Turkey 10: 5-20.

Checkel, Jefreey. (1997) Ideas and International Political Change: Soviet/Russian Behavior and the End of the Cold War. New Haven: Yale University Press.

Davutoglu, Ahmet. (1994) 21. Yuzyila Girerken Turkiye'nin Uluslararasi Konumu. In 21. Yuzyilda Turkiye'nin Hedefleri. Istanbul: MUSIAD Report no: 10.

Davutoglu, Ahmet. (2001) Stratejik Derinlik. Istanbul: Kure Yayinlari.

Davutoglu, Aнmet. (2008) Turkey's New Foreign Policy Vision: An Assessment of 2007. Insight Turkey 10: 77-96.

Davutoglu, Анmet. (2010) Turkey's Zero Problems Foreign Policy. Foreign Policy. Available at http:// www.foreignpolicy.com/articles/2010/05/20/turkeys_zero_problems_foreign_policy (Accessed December 2012.)

Davutoglu, Ahmet. (2012) Principles of Turkish Foreign Policy and Regional Political Structuring. Vision Papers 3. Ankara: SAM Center for Strategic Research, Republic of Turkey Ministry of Foreign Affairs.

Dis Ticaret Mustesarligi (Undersecretariat of Foreign Trade). (2011) Kuresel Ticarette Turkiye'nin Yeniden Konumlandirilmasi: Dis Ticarette Yeni Rotalar. Ankara: DTM.

Dueck, Colin. (2006) Reluctant Crusaders: Power, Culture, and Change in American Grand Strategy. Princeton: Princeton University Press.

Duran, Burhanettin. (2006) JDP and Foreign Policy as an Agent of Transformation. In The Emergence of a New Turkey: Democracy and the AK Parti, edited by Hakan Yavuz. Salt Lake City: University of Utah Press.

Fidan, Hakan, and Rahman Nurdun. (2008) Turkey's Role in the Global Development Assistance Community: The Case of TIKA (Turkish International Cooperation and Development Agency). Journal of Southern Europe and the Balkans 10: 93-111.

Finnemore, Martha. (1996) National Interests in International Society. Ithaca: Cornell University Press.

Finnemore, Martha. (2003) The Purpose of Intervention: Changing Beliefs about the Use of Force. Ithaca: Cornell University Press. 
Flibbert, Andrew. (2006) The Road to Baghdad: Ideas and Intellectuals in Explanations of the Iraq War. Security Studies 15: 310-352.

Goldstein, Judith, and Robert O. Keohane, Eds. (1993) Ideas and Foreign Policy: An Analytical Framework. In Ideas and Foreign Policy: Beliefs, Institutions, and Political Change, edited by Judith Goldstein and Robert O. Keohane. Ithaca: Cornell University Press.

Haas, Peter M. (1992) Introduction: Epistemic Communities and International Policy Coordination. International Organization 46: 1-35.

Hale, William. (2000) Economic Issues in Turkish Foreign Policy. In Turkey's New World: Changing Dynamics in Turkish Foreign Policy, edited by Alan Makovsky and Sabri Sayari. Washington, DC: Washington Institute for Near East Policy.

Hall, Peter, Ed. (1989) The Political Power of Economic Ideas: Keynesianism Across Nations. Princeton: Princeton University Press.

Hall, John A. (1993) Ideas and the Social Sciences. In Ideas and Foreign Policy: Beliefs, Institutions, and Political Change, edited by Judith Goldstein and Robert O. Keohane. Ithaca: Cornell University Press.

Ноoк, Steven W. (2008) Ideas and Change in U.S. Foreign Aid: Inventing the Millennium Challenge Corporation. Foreign Policy Analysis 4: 147-167.

Hopf, Ted. (1998) The Promise of Constructivism in International Relations Theory. International Security 23: 171-200.

Hopf, Ted. (2002) Social Construction of International Politics: Identities and Foreign Policies, Moscow, 1955 and 1999. Ithaca: Cornell University Press.

Kalin, Ibrahim. (2011) Soft Power and Public Diplomacy in Turkey. Perceptions: Journal of International Affairs 16: 5-24.

Kaltenthaler, Karl. (2002) German Interests in European Monetary Integration. Journal of Common Market Studies 40: 69-87.

Karaosmanoglu, Ali. (2000) The Evolution of the National Security Culture and the Military in Turkey. Journal of International Affairs 54: 199-216.

Katzenstern, Peter J. (1996) Introduction: Alternative Perspectives on National Security. In The Culture of National Security, edited by Peter Katzenstein. New York: Columbia University Press.

Kirisci, Kemal. (2009) The Transformation of Turkish Foreign Policy: The Rise of the Trading State. New Perspectives on Turkey 40 (Spring 2009): 29-57.

Kitchen, Nicholas. (2010) Systemic Pressures and Domestic Ideas: A Neoclassical Realist Model of Grand Strategy Formation. Review of International Studies 36: 117-143.

Kulaklikaya, Musa, and Rahman Nurdun. (2010) Turkey as a New Player in Development Cooperation. Insight Turkey 12: 131-145.

Larrabee, Stephen F. (2010) Turkey's New Geopolitics. Survival 52: 157-180.

Legro, Jeffrey. (2000) The Transformation of Policy Ideas. American Journal of Political Science 44: 419432.

Marsh, DAvid. (2009) Keeping Ideas in Their Place: In Praise of Thin Constructivism. Australian Journal of Political Science 44: 679-696.

Neufeld, Mark A. (1995) The Restructuring of International Relations Theory. Cambridge: Cambridge University Press.

Nye, Joseph S. J. R. (1990) Soft Power. Foreign Policy 80: 153-171.

Nye, Joseph S. J. R. (2004) Soft Power: The Means to Success in World Politics. New York: Public Affairs.

Nye, Joseph S. J. R. (2008) Public Diplomacy and Soft Power. The ANNALS of the American Academy of Political and Social Science 616: 94-109.

Oguzlu, Tarik. (2007) Soft Power in Turkish Foreign Policy. Australian Journal of International Affairs 61: 81-97.

Onis, Zrya. (2003) Turkey and the Middle East After September 11: The Importance of the EU Dimension. Turkish Policy Quarterly 2: 84-95.

Onis, Ziya, and Suhnaz Yilmaz. (2009) Between Europeanization and Euro Asianism: Foreign Policy Activism in Turkey During the AKP Era. Turkish Studies 10: 7-24.

Ozcan, Mesut. (2008) Harmonizing Foreign Policy: Turkey, the EU and the Middle East. Aldershot: Ashgate.

Ozkececi-Taner, Binnur. (2005) The Impact of Institutionalized Ideas in Coalition Foreign Policy Making: Turkey as an Example, 1991-2002. Foreign Policy Analysis 1: 249-278.

Parlak, Nukrettin. (2007) Orta Asya-Kafkasya-Balkan Ulkeleriyle Iliskiler ve Turk Dis Yardimlari (19922003). Ankara: TIKA Yayin No: 91.

Quaglia, Lucia. (2004) Italy's Policy Towards European Monetary Integration: Bringing Ideas Back In? Journal of European Public Policy 11: 1096-1111. 
Risse, Thomas, and Kathryn Sikkink. (1999) The Socialization of International Human Rights and Norms into Domestic Practices: Introduction. In The Power of Human Rights: International Norms and Domestic Change, edited by Thomas Risse, Stephen C. Ropp and Kathryn Sikkink. Cambridge: Cambridge University Press.

Risse-Kappen, Thomas. (1994) Ideas Do Not Float Freely: Transnational Coalitions, Domestic Structures, and the End of the Cold War. International Organization 48: 185-214.

Rumelili, Bahar. (2005) Civil Society and the Europeanization of Greek-Turkish Cooperation. South European Society and Politics 10: 45-56.

SAYAri, SAbri. (2000) Turkish Foreign Policy in the Post-Cold War Era. Journal of International Affairs 54: 169-183.

Schemmelfennig, Frank. (2001) The Community Trap: Liberal Norms, Rhetorical Action, and the Eastern Enlargement of the European Union. International Organization 55: 47-80.

Sikкink, Kathyrn. (1991) Ideas and Institutions: Developmentalism in Brazil and Argentina. Ithaca: Cornell University Press.

Turk Isbirligi Ve Kalkinma Ajansi (Turkish International Cooperation and Development Agency). (2006-2011) TIKA Faaliyet Raporlari 2005-2010. Ankara: TIKA.

Vardan, Omer Cinad. (2010) Preface: Turkey, The Rising Star. In Yükselen Değer Türkiye, edited by Ali Resul Usul. Istanbul: MUSIAD Report no: 67.

Weldes, Jutta. (1999) Constructing National Interests: The United States and the Cuban Missile Crisis. Minneapolis: University of Minnesota Press.

Wendt, Alexander. (1999) Social Theory of International Politics. Cambridge: Cambridge University.

Woods, Ngaire. (1995) Economic Ideas and International Relations: Beyond Rational Neglect. International Studies Quarterly 39: 161-180.

Yee, Albert S. (1996) The Causal Effects of Ideas on Politicies. International Organization 50: 69-108. 